\title{
SMART IRRIGATION ESTIMATOR
}

\section{Nadine Sangster $^{1 *}$, Aneil Ramkhalawan ${ }^{2}$, Aatma Maharajh ${ }^{3}$, Jorrel Bisnath ${ }^{4}$, Edward Cumberbatch ${ }^{5}$, Ronnie Bickramdass ${ }^{6}$, David Edwards ${ }^{7}$ and Prakash Persad $^{8}$}

\author{
1,2,3,4,5,6,7,8 Design and Manufacturing Systems, The University of Trinidad and Tobago, Trinidad \\ and Tobago \\ ${ }^{1}$ Email: nadine.sangster@utt.edu.tt*(Corresponding author) \\ ${ }^{2}$ Email: aneil.ramkhalawan@utt.edu.tt \\ ${ }^{3}$ Email: aatma.maharajh@utt.edu.tt \\ ${ }^{4}$ Email: jorrel.bisnath@utt.edu.tt \\ ${ }^{5}$ Email: edward.cumberbatch@utt.edu.tt \\ ${ }^{6}$ Email: ronnie.bickramdass@utt.edu.tt \\ ${ }^{7}$ Email: david.edwards@utt.edu.tt \\ ${ }^{8}$ Email: prakash.persad@utt.edu.tt
}

\begin{abstract}
Many of the agricultural plots within Trinidad and Tobago remain in a state of dormancy due to a critical lack of infrastructure needed for their development. This has contributed to the increasing food import bill which was some TT $\$ 5.6$ billion over the last couple of years. This overall crop irrigation project aims at assisting the farmers in setting up a proper infrastructure that will utilize natural resources. The lack of pipe water will be substituted by rainwater capture, storage and distribution via drip irrigation. The lack of power for water distribution by irrigation will be obtained by the use of solar power for the pumps. The project will be done in phases. This phase involved at creating a smart estimator to determine the water requirement and the planting land area for the 2-acre plot when the number of plants, type of plants, and the month in which the farmer chooses to start planting are chosen. It will estimate the water storage volume required for the various crops chosen based on the rainfall patterns, crop cycle and the crop water requirement. These output estimates will be based on the land area input, estimated water storage size, estimated tool shed size and produce storage area, and the type or types of crops chosen to farm by the farmer for the plot. The input parameters in the estimator can then be varied by the farmer, to help find an estimated or optimum balance of the number and type of crops, the planting land area, and the water captured and stored, based on the rainfall patterns and the unused land area. The outputs required can be similarly obtained through the use of existing models and software packages, but the tools are not 'Farmer User Friendly and readily available'.
\end{abstract}

Keywords: solar irrigation estimator, agriculture, innovation, design.

https://doi.org/10.47412/FSNX6661

\section{Introduction}

Trinidad and Tobago's food import bill has been increasing over the last few years. This can be seen from the 2018 Budget statement between the period 2003 to 2016, where our food import bill was estimated TT\$56.9 billion or average TT $\$ 4.4$ billion yearly [1]. Meanwhile, our agricultural plots remain dormant 
due to a lack of infrastructure required for development [2].This present paper stemmed from the national thrust by the Government of the Republic of Trinidad and Tobago towards food production [3]. The Caroni lands, formerly used for sugarcane production, were thought to be ideal for the utilization of growing crops, and hence farmed by the same sugarcane farmers [2]. The lands were distributed to the farmers in one, two, five and ten-acre plots with the intent of local food crop production [4]. Root vegetables and fruits were suggested but little or no infrastructure was put in place to assist the now unemployed farmers. This meant that the farmers had no water supply other than rainfall for their crops and also no power for irrigation. On numerous occasions in 2019, the Guardian newspaper stated that due to the lack of adequate rainfall in Trinidad and Tobago, the reservoirs were not being replenished as they normally do, and were asking the population to conserve water [5] [6] [7]. During this period, some farmers were left trying to acquire water from nearby ponds but were charged by authorities for not having proper documentation for water extraction [8].The farmers also lack proper road access and hence have no way of securing their crops from theft. This was reported in a newspaper article earlier this year along with other farmers across Trinidad, who were complaining of their loss of produce and equipment [9].

This paper aims at addressing some of these problems in terms of assisting the farmers in getting their farm operational to an effective and efficient status using available technologies and data. This includes effective land area usage for the selected plants by providing estimates of the number of plants, the associated water requirement and water storage to facilitate shortages during droughts. The details of this case study will be used to create the "smart irrigation estimator" but should be usable so that 'any farmer' in any geographic location can utilize the platform, provided that the associated data is placed within the library. There are existing irrigation estimator models and software, such as "Criwar 2.0" and "Cropwat" that provide these capabilities, but the operator needs to be proficient in the software [10] [11]. The proposed "Estimator" is aimed at being operated by the average farmer as a "Mobile App' on a phone, but for this current version, the farmer would need knowledge of Microsoft excel or to be assisted.

\section{Description of the Smart Irrigation Estimator}

For this estimator, it was decided that the inputs should be the size of the available land area, the type and number of crops selected for cultivation, the starting month for planting and a rough estimate of the water storage well size. In addition to this, a tool storage shed and a produce storage area would also be initially estimated. This water well storage would be used as supplement when there is a lack of rainfall to irrigate the plants via a solar powered irrigation system. The input of the type of plants would have a library of available plants with their plant area, water requirements and crop cycle to rotate or stagger the different types of crops.

From existing data based on the region, this example being Trinidad, the average rainfall patterns would be used to calculate the water deficit based on the types of plants and associated life cycles. This deficit would determine the water storage area required, and also, based on the estimated amount of monthly rainfall, if the estimated volume would suffice the plant water deficit during the periods of no rainfall. If not, the farmer would have to provide water from an external source to supplement this shortage or vary the parameters on the estimator to balance or eliminate the deficit by staggering plant cycles during the year as well as varying the number of plants. Also, with this period of rainfall shortage, the daily power required for those days for irrigation can be calculated as in our previous paper [2]. This power would be supplied by solar energy and the effective solar area required [2]. However, this estimate will not be incorporated in this version of the estimator.

The crops used for this paper are short-term crops with the maximum crop cycle being one year for bananas. 
The following crops were selected for the initial estimator, but the library can be increased and modified based on region, climate, seasonal plants, crop rotation and many other scenarios:

- Pepper

- Tomato

- Potato

- Sweet Potato
- Carrot

- Lettuce

- Cabbage

- Water melon
- Cucumber

- Plantain/Banana

- Pumpkin

- Green Peas

The following Functional Analysis Systems Technique (FAST) chart (

Figure 30) displays a summary of the basic function of how the estimator would operate.

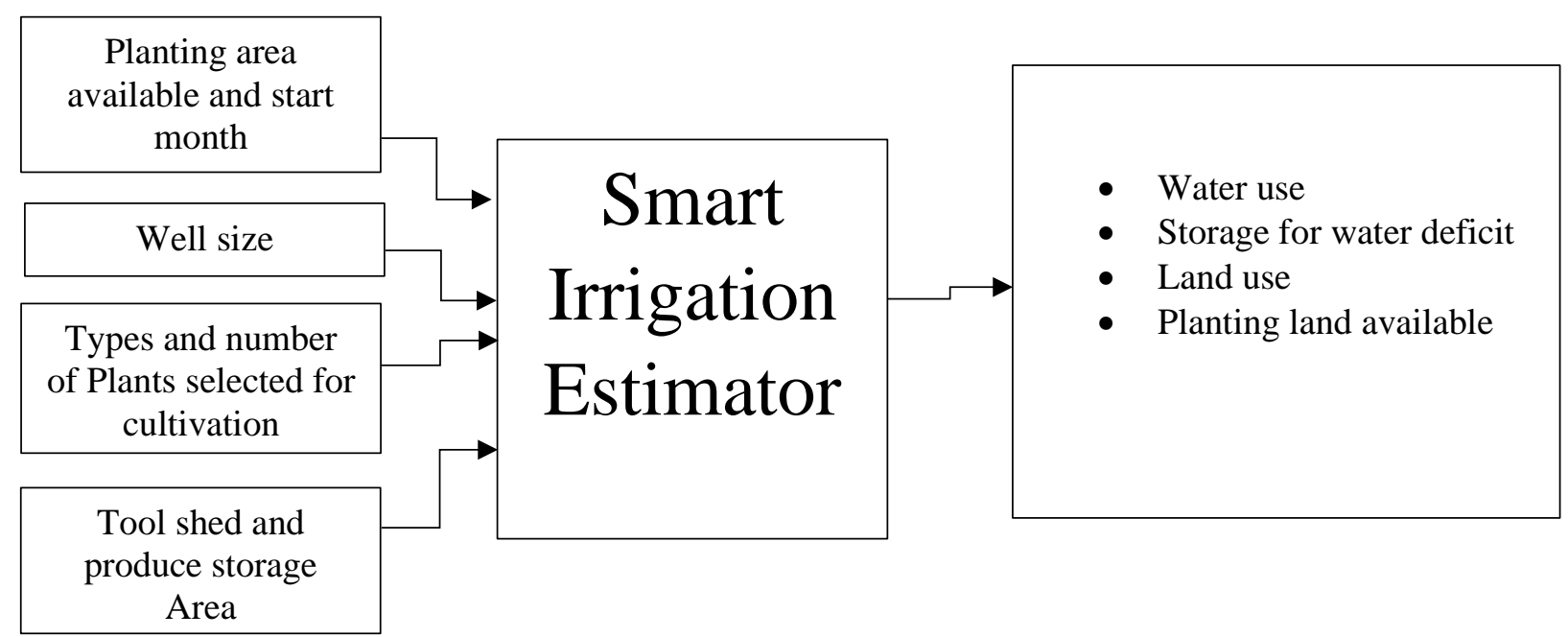

Figure 30: Fast Chart of the Smart Irrigation Estimator

\section{Data Gathering}

Data was gathered and tabulated to create the library for the Smart estimator to refer to, for data to calculate the outputs based on the selected inputs by the farmers.

For this scenario the following was used,

$\begin{aligned} \text { Using } 2 \text { acre plots } & =8093.71 \mathrm{~m}^{2} \\ \text { Using tool shed Size as }(4 \mathrm{~m} * 4 \mathrm{~m}) & =16 \mathrm{~m}^{2} \\ \text { Using produce storage as }(3 \mathrm{~m} \times 6 \mathrm{~m}) & =18 \mathrm{~m}^{2} \\ \text { Total unplantable Area } & =34 \mathrm{~m}^{2} \\ \text { Therefore, Planting area } & =8093.71-34 \\ & =8059.71 \mathrm{~m}^{2}\end{aligned}$


Assumptions:

- Initial volume of water in the estimated water storage well was $100 \%$ due to the assumption that water would have been collected the previous year

- For the crop cycle range period, the maximum cycle period was used to ensure that maximum water requirement can be met

Table 16 presents the crops selected for this study with its associated plant land area required for growth throughout its life cycle, as well as its water requirements per life cycle per plant. The methods used determined these requirements by obtaining crop evapotranspiration (ETo), which denotes the level of evapotranspiration for different climatic conditions. These methods are the Blaney-Criddle, the Radiation, the Penman and Pan Evaporation methods, each requiring climatic data. To derive the evapotranspiration for a specific crop, relationships between crop evapotranspiration (ET crop) and reference crop evapotranspiration (ETo) for different crops, stages of growth, length of growing season and prevailing climatic conditions were used.

Plant life cycle is normally given as a range between a minimum and maximum life cycle. For this paper, the upper limit of the plant growth cycle (maximum crop cycle period) was used. These values are then fed to the smart estimator for calculations.

Table 16: Showing the Selected crops with its associated data for the Smart Estimator

\begin{tabular}{|c|c|c|c|c|}
\hline $\begin{array}{c}\text { Crops } \\
\text { selected }\end{array}$ & $\begin{array}{c}\text { Area required } \\
\text { per plant }\left(\mathrm{m}^{2}\right)\end{array}$ & $\begin{array}{c}\text { Crop water } \\
\text { requirement }(\mathrm{mm})\end{array}$ & $\begin{array}{c}\text { Crop water requirement } \\
\text { per plant }\left(\mathrm{m}^{3}\right)\end{array}$ & $\begin{array}{c}\text { Max. Crop cycle } \\
\text { period (days) }\end{array}$ \\
\hline Pepper & 9.00 & 900.00 & 0.90 & 210.00 \\
\hline Tomato & 0.36 & 800.00 & 0.80 & 135.00 \\
\hline Potato & 0.12 & 625.00 & 0.63 & 105.00 \\
\hline Sweet Potato & 0.56 & 675.00 & 0.68 & 150.00 \\
\hline Carrot & 0.05 & 980.00 & 0.98 & 140.00 \\
\hline Lettuce & 0.06 & 254.00 & 0.25 & 120.00 \\
\hline Cabbage & 0.20 & 500.00 & 0.50 & 130.00 \\
\hline Cucumber & 3.00 & 944.00 & 0.94 & 120.00 \\
\hline Pumpkin & 9.00 & 686.00 & 0.69 & 365.00 \\
\hline Water melon & 6.00 & 600.00 & 0.60 & 100.00 \\
\hline $\begin{array}{c}\text { Plantain } \\
\text { /Banana }\end{array}$ & 4.00 & 1700.00 & 1.70 & \\
\hline Green Peas & 0.02 & 363.00 & 0.36 & \\
\hline
\end{tabular}

[11] [12] [13] [14] [15] [16] [17] [18] [19]

Table 17 presents the average monthly rainfall from two sources for Trinidad and then the average was calculated as data input for the smart estimator. The data used was to give an approximation of the rainfall that exists across Trinidad. Rainfall Data specific to areas may not be readily available, hence the reason 
for the assumption. This is the reason for using two data sets and the average used. As more data is gathered for specific regions, the estimator can be improved to reflect this.

Table 17: Displays the Average Monthly Rainfall for Trinidad from two separate sources [20] [21]

\begin{tabular}{|l|c|c|c|c|}
\hline \multicolumn{1}{|c|}{ Month } & $\begin{array}{c}\text { Number of } \\
\text { Days }\end{array}$ & $\begin{array}{c}\text { Avg. Monthly Rainfall } \\
(\mathrm{mm})\end{array}$ & $\begin{array}{c}\text { Avg. Monthly Rainfall } \\
(\mathrm{mm})\end{array}$ & Average (mm) \\
\hline January & 31 & 58 & 70 & 64 \\
\hline February & 28 & 54 & 40 & 47 \\
\hline March & 31 & 49 & 30 & 39.5 \\
\hline April & 30 & 55 & 40 & 47.5 \\
\hline May & 31 & 78 & 110 & 206.5 \\
\hline June & 30 & 163 & 250 & 220.5 \\
\hline July & 31 & 201 & 240 & 180.5 \\
\hline August & 31 & 180 & 230 & 200 \\
\hline September & 30 & 181 & 180 & 204 \\
\hline October & 31 & 230 & 170 & 154 \\
\hline November & 30 & 218 & 190 & \\
\hline December & 31 & 168 & 140 & \\
\hline
\end{tabular}

\section{Results and Discussion}

Figure 31 below shows a snapshot of the Smart estimator inputs, in which the farmer has to fill in. The acreage of the farm can be increased or decreased in two-acre plot size increments. The water storage well size is based on a percentage of the total land size which can also be varied. The effective planting area was calculated by using the total plot area minus the tool shed area, the produce storage area and the water storage area. The tool shed and produce area will be determined by the farmer.

The crop information area provides the farmer with the user input information for the crop number which displays the order in which he wants to start planting according to the starting month. In the above scenario, he enters hot peppers as crop 1. He chooses 500 plants and starts in January. A planting area of $4500 \mathrm{~m}^{2}$, a crop cycle of 7 months (210 days) and a monthly water requirement of $77.14 \mathrm{~m}^{3}$ for the 500 plants are generated in Figure 31 above based on the hot pepper plant information from Table 16. Figure 32 below shows a snapshot of the outputs, 'land use and water use for the hot pepper' crop cycle which is 7 months. Based on this, it further calculates the remaining land available for planting other crops as well as the water balance after water usage by the hot pepper plants and the water addition to the storage tank due to rainfall for that month.

For his second crop in Figure 31, he chooses 1000 tomato plants and selects March as the start month for planting. In Figure 32 below, under the crop 2 tab, you can see that planting begins in March which is shown by the $360 \mathrm{~m}^{2}$ of land use by the 1000 tomato plants with an associated $213 \mathrm{~m}^{3}$ of required water. The crop cycle for tomatoes is 4.5 months (135 days) which is approximated to 5 months hence these value span until July. The total land use has now changed from $4500 \mathrm{~m}^{2}$ to $4860 \mathrm{~m}^{2}$ because of the addition of the $360 \mathrm{~m}^{2}$ of tomato plants added to the field. The total water usage has also increase from $77 \mathrm{~m}^{3}$ for pepper, to 
$290 \mathrm{~m}^{3}$ due to the additional water required by the tomato plants being added. As the crop 1 (hot pepper) cycle comes to an end, you can also see that another cycle of hot peppers would be started in August under crop 5.

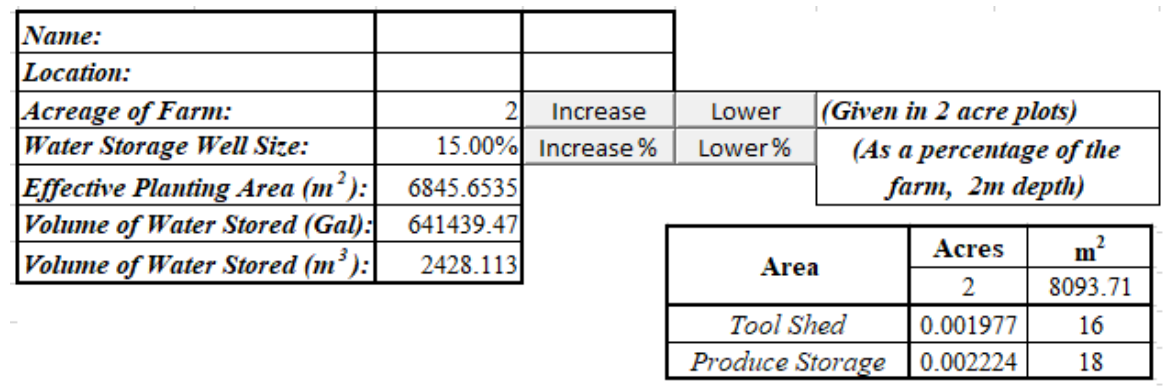

\begin{tabular}{|c|c|c|c|c|c|c|c|}
\hline \multicolumn{8}{|c|}{ Crop Information } \\
\hline Crop Number & Crop Type & \begin{tabular}{|c|}
$\begin{array}{c}\text { Number of } \\
\text { Plants }\end{array}$ \\
\end{tabular} & $\begin{array}{c}\text { Start } \\
\text { Month }\end{array}$ & \begin{tabular}{|c|} 
Planting Area \\
$\left(\mathrm{m}^{2}\right)$
\end{tabular} & \begin{tabular}{|c|} 
Planting \\
Area (Acres)
\end{tabular} & $\begin{array}{c}\text { Crop Cycle } \\
\text { (Months) }\end{array}$ & $\begin{array}{c}\text { Mth Water } \\
\text { Requirements }\left(\mathrm{m}^{3}\right)\end{array}$ \\
\hline \begin{tabular}{|c|}
1 \\
\end{tabular} & Hot Peppers & 500 & January & 4500 & 1.11 & 7.0 & 77.14 \\
\hline 2 & Tomatoes & 1000 & March & 360 & 0.09 & 4.5 & 213.33 \\
\hline 3 & Carrot & 1000 & August & 45 & 0.01 & 4.7 & 252.00 \\
\hline 4 & Lettuce & 1000 & August & 202.5 & 0.05 & 1.2 & 261.26 \\
\hline 5 & Hot Peppers & 500 & August & 4500 & 1.11 & 7.0 & 77.14 \\
\hline 6 & Tomatoes & 200 & July & 72 & 0.02 & 4.5 & 42.67 \\
\hline 7 & Carrot & 1000 & October & 45 & 0.01 & 4.7 & 252.00 \\
\hline 8 & & & June & & & & \\
\hline \multicolumn{8}{|l|}{9} \\
\hline \multicolumn{8}{|l|}{10} \\
\hline \multicolumn{8}{|l|}{11} \\
\hline 12 & & & & & & & \\
\hline
\end{tabular}

Figure 31: Displays a snapshot of the input section of the Smart Estimator

Therefore, as the farmer keeps adding different crops to the estimator, whether staggering the planting time or planting during the same month, he can gauge his available land remaining and his water usage per crop type per month and hence his storage based on that month's rainfall data. So based on this scenario, by adding more crops, he will eventually have no land available and/or not enough water available. It is at this point he will have to toggle with the values to create some sort of balance where he can manage with the resources he has available or choose to source an external supply to supplement the deficit.

In Figure 32 below, under the tab 'Available Land', from January to February, the land value goes negative. This was purposely highlighted to demonstrate that by adding to much crop and/or plants, the land area will eventually be filled to capacity. This is where the farmer now has to restructure his planting plan by varying the values in the Smart estimator until balance is restored for land area and water supply. In terms of the water supply, the farmer also has to ensure that a surplus of water should exist in the storage area at the end of the year to ensure that he can start replanting or even continue planting based on the staggering of the crops for continuity. This can also be supplemented if an external source of water is used. This surplus would also cater for lack of rainfall or droughts. 


\begin{tabular}{|c|c|c|c|c|c|c|c|c|c|c|c|c|c|c|c|c|c|c|c|}
\hline \multirow[b]{2}{*}{ Mon. } & \multicolumn{2}{|c|}{ Crop 1} & \multicolumn{2}{|c|}{ Crop 2} & \multicolumn{2}{|c|}{ Crop 3} & \multicolumn{2}{|c|}{ Crop 4} & \multicolumn{2}{|c|}{ Crop 5} & \multicolumn{2}{|c|}{ Crop 6} & \multicolumn{2}{|c|}{ Crop 7} & \multirow{2}{*}{$\begin{array}{c}\text { Total } \\
\text { Land } \\
\text { Use } \\
\left(\mathbf{m}^{2}\right)\end{array}$} & \multirow{2}{*}{\begin{tabular}{|c|} 
Total \\
Water \\
Use \\
$\left(\mathbf{m}^{3}\right)$
\end{tabular}} & \multirow[b]{2}{*}{$\begin{array}{c}\text { Available } \\
\text { Land } \\
\left(\mathbf{m}^{2}\right)\end{array}$} & \multirow{2}{*}{$\begin{array}{c}\text { Potential } \\
\text { Rainfall } \\
\text { Capture } \\
\left(\mathbf{m}^{3}\right)\end{array}$} & \multirow{2}{*}{\begin{tabular}{|c} 
Starting \\
Water \\
Storage \\
Balance \\
$\left(\mathbf{m}^{\mathbf{3}}\right)$ \\
\end{tabular}} \\
\hline & $\begin{array}{c}\text { Land } \\
\text { Use } \\
\left(\mathbf{m}^{2}\right)\end{array}$ & $\begin{array}{c}\text { Water } \\
\text { Use } \\
\left(\mathbf{m}^{3}\right)\end{array}$ & $\begin{array}{c}\text { Land } \\
\text { Use } \\
\left(\mathbf{m}^{2}\right)\end{array}$ & \begin{tabular}{|c} 
Water \\
Use \\
$\left(\mathbf{m}^{3}\right)$ \\
\end{tabular} & $\begin{array}{l}\text { Land } \\
\text { Use } \\
\left(\mathbf{m}^{2}\right)\end{array}$ & \begin{tabular}{|c} 
Water \\
Use \\
$\left(\mathbf{m}^{3}\right)$ \\
\end{tabular} & $\begin{array}{l}\text { Land } \\
\text { Use } \\
\left(\mathbf{m}^{2}\right)\end{array}$ & \begin{tabular}{|c} 
Water \\
Use \\
$\left(\mathbf{m}^{3}\right)$
\end{tabular} & \begin{tabular}{|c} 
Land \\
Use \\
$\left(\mathbf{m}^{2}\right)$
\end{tabular} & \begin{tabular}{|l} 
Water \\
Use \\
$\left(\mathbf{m}^{\mathbf{3}}\right)$ \\
\end{tabular} & $\begin{array}{c}\text { Land } \\
\text { Use } \\
\left(\mathbf{m}^{2}\right)\end{array}$ & \begin{tabular}{|l} 
Water \\
Use \\
$\left(\mathbf{m}^{3}\right)$ \\
\end{tabular} & $\begin{array}{c}\text { Land } \\
\text { Use } \\
\left(\mathbf{m}^{2}\right) \\
\end{array}$ & \begin{tabular}{|l} 
Water \\
Use \\
$\left(\mathbf{m}^{3}\right)$
\end{tabular} & & & & & \\
\hline Jan & 4500 & 77 & & & & & & & & & & & & & 4500 & 77 & 2346 & 207 & 2428 \\
\hline Feb & 4500 & 77 & & & & & & & & & & & & & 4500 & 77 & 2346 & 152 & 2558 \\
\hline Mar & 4500 & 77 & 360 & 213 & & & & & & & & & & & 4860 & 290 & 1986 & 128 & 2633 \\
\hline Apr & 4500 & 77 & 360 & 213 & & & & & & & & & & & 4860 & 290 & 1986 & 154 & 2471 \\
\hline May & 4500 & 77 & 360 & 213 & & & & & & & & & & & 4860 & 290 & 1986 & 304 & 2334 \\
\hline Jun & 4500 & 77 & 360 & 213 & & & & & & & & & & & 4860 & 290 & 1986 & 669 & 2348 \\
\hline Jul & 4500 & 77 & 360 & 213 & & & & & & & 360 & 213 & & & 5220 & 504 & 1626 & 714 & 2726 \\
\hline Aug & & & & & 45 & 252 & 203 & 261 & 4500 & 77 & 360 & 213 & & & 5108 & 804 & 1738 & 664 & 2936 \\
\hline Sep & & & & & 45 & 252 & & & 4500 & 77 & 360 & 213 & & & 4905 & 542 & 1941 & 584 & 2796 \\
\hline Oct & & & & & 45 & 252 & & & 4500 & 77 & 360 & 213 & 45 & 252 & 4950 & 794 & 1896 & 647 & 2838 \\
\hline Nov & & & & & 45 & 252 & & & 4500 & 77 & 360 & 213 & 45 & 252 & 4950 & 794 & 1896 & 660 & 2691 \\
\hline Dec & & & & & 45 & 252 & & & 4500 & 77 & & & 45 & 252 & 4590 & 581 & 2256 & 499 & 2557 \\
\hline Jan & 4500 & 77 & & & & & & & 4500 & 77 & & & 45 & 252 & 9045 & 406 & -2199 & 207 & 2474 \\
\hline Feb & 4500 & 77 & & & & & & & 4500 & 77 & & & 45 & 252 & 9045 & 406 & -2199 & 152 & 2275 \\
\hline Mar & 4500 & 77 & 360 & 213 & & & & & & & & & & & 4860 & 290 & 1986 & 128 & 2021 \\
\hline Apr & 4500 & 77 & 360 & 213 & & & & & & & & & & & 4860 & 290 & 1986 & 154 & 1858 \\
\hline May & 4500 & 77 & 360 & 213 & & & & & & & & & & & 4860 & 290 & 1986 & 304 & 1722 \\
\hline Jun & 4500 & 77 & 360 & 213 & & & & & & & & & & & 4860 & 290 & 1986 & 669 & 1736 \\
\hline Jul & 4500 & 77 & 360 & 213 & & & & & & & 360 & 213 & & & 5220 & 504 & 1626 & 714 & 2114 \\
\hline Aug & & & & & 45 & 252 & 203 & 261 & 4500 & 77 & 360 & 213 & & & 5108 & 804 & 1738 & 664 & 2324 \\
\hline Sep & & & & & 45 & 252 & & & 4500 & 77 & 360 & 213 & & & 4905 & 542 & 1941 & 584 & 2184 \\
\hline Oct & & & & & 45 & 252 & & & \begin{tabular}{|l|l}
4500 \\
\end{tabular} & 77 & 360 & 213 & 45 & 252 & 4950 & 794 & 1896 & 647 & 2226 \\
\hline Nov & & & & & 45 & 252 & & & 4500 & 77 & 360 & 213 & 45 & 252 & 4950 & 794 & 1896 & 660 & 2079 \\
\hline Dec & & & & & 45 & 252 & & & 4500 & 77 & & & 45 & 252 & 4590 & 581 & 2256 & 499 & 1945 \\
\hline
\end{tabular}

Figure 32: Displays a snapshot of the Outputs of the Smart Estimator

The number of beds and drainage, placement of the storage area was not computed in this paper due to complexity and varying topography of land in general. For example, the land may be sloping to one side and hence the water run-off will be in that direction. Therefore the water storage should be located on that side of the land. Ideally, the pond should be centered in the land area if the land is flat, to reduce on piping and pumping for irrigation, but this would not always be the situation.

\section{Conclusion}

It can be concluded that the estimator will be very useful to farmers due to the fact that it can save time and money by simulating the various number of planting scenarios based on land area, number and type of plants, and volume of water collected and stored via the rainfall data. It will help them maximize their area usage and production costs by mixing high water crops with low water crops to balance their water reserves and water collection. This would help maximize their production. Other systems may be implemented later to improve and/or modify the estimator to included other factors such as security, nutrient control distribution based on plant needs and growth stages and smart pest control systems.

\section{Recommendations for Modification of the Smart Estimator}

- The estimator would later be modified to calculate the bed sizes and drain sizes to separate the beds with the drains leading to some catchment area for storage.

- For practical purposes, the solar area can be housed on the roof top of the 'tool shed' and 'produce storage area' to maximize on planting space. It will also assist in reducing the evaporation of the water storage. 
- The water storage area or pond can be contained under the tool shed and produce storage areas to maximize on space but this will lead to an increased capital cost.

- This area can also be used for securing the pumps and filtration systems that may be required for irrigation. Securing of these equipment aims at both protection from the environmental elements as well as by immoral societal elements via theft [9].

- The estimated volume of water deficit can be used to determine the depth of the storage area and/or be oversized to incorporate any further droughts. However, the capital cost would be increased for construction of a structure over the well.

\section{Acknowledgements}

The authors thank Mr. Seunarine Persad, Senior Instructor at The University of Trinidad and Tobago, for information related to the area of study and BPTT for the award of a renewable energy research grant.

\section{References}

[1] Ministry of Finance, "Budget Statement 2018," Ministry of Finance, Port of Spain, Trinidad and Tobago, 2017.

[2] P. Persad, N. Sangster, E. Cumberbatch, A. Ramkhalawan and A. Maharajh, "Investigating the Feasibility of Solar Powered Irrigation for Food Crop Production: A Caroni Case," The Journal of the Association of Professional Engineers of Trinidad and Tobago, pp. 61-65, 2011.

[3] C. Imbert, "Changing the Paradigm: Putting the Economy on a Sustainable Path," Government of the Republic of Trinidad and Tobago, Port-of-Spain, 2018.

[4] S. Persad, "Irrigation and Water Management in Tobago," The University of Trinidad and Tobago, Piarco, 2007.

[5] S. Wilson, "Water Dam Low," Guardian Newspaper, p. A5, 30 June 2019.

[6] E. Team, "Water Distress," Express Newspaper, p. 12, 26 April 2019.

[7] W. Gibbings, "The Water Challenge," Guardian Newspaper, 16 January 2019.

[8] S. Hassanali, "Crops Wither as WASA seizes more pumps," Guardian Newspaper, p. A7, 21 May 2019.

[9] R. De Silva, “Thieves Stressing Farmers,” Guardian Newspaper, p. A9, 18 January 2019.

[10] M. G. Bos, J. Vos and R. A. Feddes, CRIWAR 2.0: A simulation model on Crop Irrigation Water Requirements, (Version 2.0 ed., Ilri publiccation, 46). Wageningen, The Netherlands: International Institute for Land Reclamation and Improvement, 1996.

[11] L. a. W. D. D. o. FAO, "Food and Agriculture Organization of the United Nations," United Nations, January 1945. [Online]. Available: http://www.fao.org/home/en/. [Accessed 21 February 2020].

[12] J. Biernbaum, "College of Agriculture \& Natural Resources," Michigan State University, 1 January 1964. [Online]. Available: https://www.canr.msu.edu/. [Accessed 5 December 2019].

[13] Government of Kerala, "Farm Information Bureau," Department of Agriculture Development and Farmers' Welfare, 2012. [Online]. Available:

https://www.fibkerala.gov.in/index.php?option=com_content\&task=view\&id=354\&Itemid=124. [Accessed 6 December 2019].

[14] C. Brouwer, A. Goffeau and M. Heibloem, "Irrigation Water Management: Training Manual No. 1 Introduction to Irrigation," FAO - FOOD AND AGRICULTURE ORGANIZATION OF THE UNITED NATIONS, 1985. [Online]. Available: http://www.fao.org/3/r4082e/r4082e00.htm\#Contents. [Accessed 512 2019]. 
[15] C. Quezada, S. Fischer, J. Campos and D. Ardiles, "Water requirements and water use efficiency of carrot under drip irrigation in a hap-loxerand soil," Journal of soil science and plant nutrition, vol. 11, no. 1, pp. 16-28, 2011.

[16] G. Marek, "San Francisco Chronicle / SFGate.com," SFGATE, 1994. [Online]. Available: https://homeguides.sfgate.com/can-water-affect-peas-growth-75070.html. [Accessed 512 2019].

[17] T. Napier, "New South Wales Government," Department of Primary Industries (DPI), November 2009. [Online]. Available:

https://www.dpi.nsw.gov.au/_data/assets/pdf_file/0004/311485/Pumpkin-production.pdf. [Accessed 612 2019].

[18] T. Editors, “Good Housekeeping,” Everything You Need to Know About Growing Crisp Cucumbers, 12 July 2018. [Online]. Available: https://www.goodhousekeeping.com/home/gardening/a20707040/growing-cucumbers/. [Accessed 7 12 2019].

[19] D. Drost, "Utah State University," Home Gardening: Lettuce in the Garden, June 2010. [Online]. Available: https://digitalcommons.usu.edu/cgi/viewcontent.cgi?article=1248\&context=extension_curall. [Accessed 712 2019].

[20] S. Persad, Presentation 4: Soil and water Management: Irrigation and Water management-Crop water requirements, The University of Trinidad and Tobago, 2007.

[21] W. Atlas, "Weather Atlas," 2002. [Online]. Available: https://www.weather-atlas.com/en/trinidadand-tobago/tobago-climate\#rainfall. [Accessed 201 2020].

[22] C. t. Travel, "Climates to Travel," [Online]. Available:

https://www.climatestotravel.com/climate/trinidad-and-tobago. [Accessed 301 2020]. 